\title{
Antimicrobial multiple resistance index, minimum inhibitory concentrations, and extended-spectrum beta-lactamase producers of Proteus mirabilis and Proteus vulgaris strains isolated from domestic animals with various clinical manifestations of infection
}

\author{
Índice de resistência múltipla aos antimicrobianos, concentração \\ inibitória mínima e ESBL fenotípica em linhagens de Proteus \\ mirabilis e Proteus vulgaris isoladas de diferentes afecções em \\ animais domésticos
}

\author{
Vanessa Zappa ${ }^{1 *}$; Carmen Alicia Daza Bolaños²; Carolina Lechinski de Paula²; \\ João Luis Revolta Callefe ${ }^{3}$; Ana Carolina Alves²; \\ Amanda Bonalume Cordeiro de Morais'; Simony Trevizan Guerra ${ }^{2}$; \\ Marina Chaves Cabrini ${ }^{4}$; Priscilla Anne Melville ${ }^{5}$ Márcio Garcia Ribeiro ${ }^{6}$
}

\begin{abstract}
Proteus spp. are opportunistic multidrug resistant enterobacteria associated with diverse clinical diseases in domestic animals. However, Proteus infections in domestic animals are often misdiagnosed or considered contaminants in microbiological cultures rather than a primary agent of disease. Descriptions of Proteus infections in domestic animals are typically restricted to case reports, retrospective studies, or surveillance of other microorganisms. The present study investigated multiple antibiotic resistance indices, minimum inhibitory concentrations (MICs), and ESBL production in 73 strains of Proteus mirabilis $(\mathrm{n}=69)$ and Proteus vulgaris $(\mathrm{n}=4)$ isolated from domestic animals with various clinical manifestations. In dogs, the pathogen was most commonly associated with cystitis (48.21), enteritis (21.42\%), otitis (14.29\%), and conjunctivitis (3.57\%). In bovines, the microorganism was predominant in cases of enteritis $(22.22 \%)$, abscess $(11.11 \%)$, otitis $(11.11 \%)$, omphalitis $(11.11 \%)$, and peritonitis $(11.11 \%)$, and in organ fragments $(11.11 \%)$. In equines $(50.0 \%)$ and cats $(100.0 \%)$, diarrhea was the main clinical sign. In vitro standard disk diffusion assay showed that the most effective antimicrobials against the isolates were imipenem (98.63), norfloxacin (95.89), amikacin (95.89), levofloxacin (90.41), ceftriaxone (87.64), and florfenicol (87.67). In contrast, the isolates commonly showed resistance to
\end{abstract}

\footnotetext{
${ }^{1}$ Prof $^{a}$, Doenças Infecciosas dos Animais, Faculdade de Ensino Superior e Formação Integral, FAEF, Garça, SP, Brasil. E-mail: direcao@faef.br

2 Discentes, Pós-Graduação, Programa de Medicina Veterinária, Área de Saúde Animal, Saúde Pública Veterinária e Segurança Alimentar, Faculdade de Medicina Veterinária e Zootecnia, Universidade Estadual Paulista, UNESP, Botucatu, SP, Brasil. E-mail: carmen.dazab@hotmail.com; ca_lechinski@yahoo.com.br; anacveterinaria@hotmail.com; amandabonalume@gmail. com; simony_guerra@hotmail.com;

${ }^{3}$ Discente, Medicina Veterinária, Faculdade de Medicina Veterinária e Zootecnia, UNESP, Botucatu, SP, Brasil. E-mail: joaocallefe@gmail.com

${ }^{4}$ Discente, Medicina Veterinária, Faculdade de Ensino Superior e Formação Integral, FAEF, Garça, SP, Brasil. E-mail: marinacabrini_sp@hotmail.com

5 Técnica em laboratório de nível superior, Faculdade de Medicina Veterinária e Zootecnia, Universidade de São Paulo, USP, SP, Brasil. Email: melville@usp.br

${ }^{6}$ Prof., Adjunto, Enfermidades Infecciosas dos Animais, Departamento de Higiene Veterinária e Saúde Pública, Faculdade de Medicina Veterinária e Zootecnia, UNESP, Botucatu, SP, Brasil. E-mail: mgribeiro@fmvz.unesp.br

* Author for correspondence
} 
novobiocin (95.89), azithromycin (57.53), and trimethropim/sulfamethoxazole (39.73). Among the 73 isolates, the efficacy of amoxicillin/clavulanic acid, gentamicin, ceftriaxone, and ciprofloxacin according to MICs was $87.67 \%, 86.30 \%, 84.93 \%$, and $82.19 \%$, respectively. The $\mathrm{MIC}_{50}$ values of amoxicillin/clavulanic acid, ceftriaxone, ciprofloxacin, and gentamicin were, respectively, 1.0, 0.004, 0.03 , and $1.0 \mu \mathrm{g} / \mathrm{mL}$. Thirty-three strains (45.21\%) showed a antimicrobial multiple resistance index of $\geq 0.3$. Multidrug resistance profiles of isolates were observed most frequently in dogs $(n=25 ; 75.76 \%)$, particularly in those with cystitis $(\mathrm{n}=13 ; 52.0 \%)$, followed by bovines $(\mathrm{n}=4 ; 12.12 \%)$, equines $(\mathrm{n}$ $=2 ; 6.06 \%)$, and cats $(\mathrm{n}=2 ; 6.06 \%)$. Two $(2.7 \%)$ strains, obtained from canine skin and feces, were diagnosed phenotypically as ESBL-producers. Here, we observed the diversity of Proteus infections in domestic animals. The presence of multidrug-resistant isolates and ESBL-producers reinforces the need for appropriate antimicrobial use and in vitro antimicrobial tests to support therapy.

Key words: Proteus sp. Multidrug resistant. Extended-spectrum beta-lactamase. Livestock. Companion animals.

\section{Resumo}

Proteus spp. são enterobactérias oportunistas, multirresistentes aos antimicrobianos, associadas a diversas infecções em animais domésticos. No entanto, as infecções por Proteus em animais de produção e de companhia são negligenciadas ou, por vezes, o patógeno é considerado "contaminante", ainda que em infecções como agente primário. Os registros de infecções por Proteus sp. em animais domésticos estão restritos aos relatos de casos, estudos retrospectivos ou compondo estudos com outros microorganismos. O presente estudo investigou o índice de resistência múltipla (IRMA) e a concentração inibitória mínima (CIM) de 73 Proteus mirabilis $(\mathrm{n}=69)$ e Proteus vulgaris $(\mathrm{n}=4)$ a diferentes antimicrobianos, bem com a produção fenotípica de ESBL, em isolados obtidos de várias manifestações clínicas em animais domésticos. Em cães, o micro-organismo foi identificado predominantemente em casos de cistite $(48,21 \%)$, enterite $(21,42 \%)$, otite $(14,29 \%)$ e conjuntivite $(3,57 \%)$. Nos bovinos, o agente foi isolado predominantemente de casos enterite $(22,22 \%)$, abscesso $(11,11 \%)$, otite $(11,11 \%)$, onfalite $(11,11 \%)$, peritonite $(11,11 \%)$, metrite $(11,11 \%)$ e em fragmento de órgão $(11,11 \%)$. Nos equinos $(50,0 \%)$ e felinos $(100,0 \%)$ o micro-organismo foi isolado principalmente de enterite. A maior sensibilidade dos isolados no teste "in vitro" de difusão com discos foi observada para imipeném $(98,63 \%)$, norfloxacino $(95,89 \%)$, amicacina $(95,89 \%)$, levofloxacino $(90,41 \%)$, ceftriaxona $(87,64 \%)$ e florfenicol $(87,67 \%)$, enquanto a maior resistência das linhagens foi observada para novobiocina $(95,89 \%)$, azitromicina $(57,53 \%)$ e sulfametoxazole-trimetropim $(39,73 \%)$. Dentre as 73 linhagens, a eficácia da amoxicilina/ácido clavulânico, gentamicina, ceftriaxona e ciprofloxacino utilizando o teste de CIM foi, respectivamente, $87,67 \%, 86,30 \%, 84,93 \%$ e $82,19 \%$. A CIM $_{50}$ para amoxicilina/ácido clavulânico, ceftriaxona, ciprofloxaicno e gentamicina foi, respectivamente, $1,0 \mu \mathrm{g} / \mathrm{mL}, 0,004 \mu \mathrm{g} / \mathrm{mL}$, $0,03 \mu \mathrm{g} / \mathrm{mL}$ e $1,0 \mu \mathrm{g} / \mathrm{mL}$. O índice de resistência múltipla aos antimicrobianos (IRMA $\geq 0,3$ ) foi observado em 33 (45,21\%) linhagens, variando entre 0,1 a 1 . Entre os isolados com perfis de multirresistência, a maior ocorrência foi observada em cães $(\mathrm{n}=25 ; 75,76 \%)$, particularmente em animais com cistite $(\mathrm{n}=13$; $52,0 \%)$, seguido pelos bovinos $(n=4 ; 12,12 \%)$, equinos $(n=2 ; 6,06 \%)$ e felinos $(n=2 ; 6,06 \%)$. A presença fenotípica de ESBL foi identificada em dois $(2,7 \%)$ isolados obtidos de dermatite e fezes de cães. Inferese a diversidade de infecções causadas por Proteus em animais domésticos, a presença de isolados ESBL-positivos e multirresistentes aos antimicrobianos, reforçando a importância da instituição do tratamento do patógeno com respaldo em testes "in vitro" de sensibilidade microbiana e do uso racional de antimicrobianos no tratamento de infecções em animais domésticos.

Palavras-chave: Proteus sp. Multirresistência aos antimicrobianos. Beta-lactamases de espectro estendido. Animais de produção e de companhia. Manifestações clínicas. 


\section{Introduction}

Proteus species are members of the animal and human enteric microbiota (KOENIG, 2012; MURRAY et al., 2007). These bacteria are also found in animal breeding facilities and contaminate water, food, vegetables, utensils, equipment, and surgical instruments used on animals (QUINN et al., 2011).

Fecal elimination and a wide distribution in the environment facilitate opportunistic Proteus infections in animals and humans (MURRAY et al., 2007; SONGER; POST, 2005). Although urinary tract infections and otitis are the most frequent infections of Proteus spp. in domestic animals (QUINN et al., 2005, 2011), various other clinical conditions have been described, including septicemia, neonatal enteritis, uterine infections, prostatitis, mastitis, and dermatitis (KOENIG, 2012; MURRAY et al., 2007; PHILPOT; NICKERSON, 2002; RADOSTITS et al., 2007).

An increase in infections by opportunistic enterobacteria, including those caused by Proteus spp. in domestic animals is a cause for concern, because an increase in this condition is generally secondary to the improper use of antimicrobials during treatments or occurs after invasive diagnostic and surgical procedures (GIGUÈRE et al., 2010).

Because there is a higher incidence of human and animal infections caused by more pathogenic enterobacteria such as Escherichia coli, Salmonella spp., Klebsiella pneumoniae, Shigella spp., and Enterobacter spp., infections by Proteus spp. do not receive attention or these species are considered to be contaminants even when they are the primary causal agents. However, Proteus spp. have been increasingly recovered from humans and animals with various clinical manifestations and multidrugresistant isolates have emerged as a public health concern (O'HARA et al., 2000; QUINN et al., 2011; SONGER; POST, 2005). In Brazil, studies of Proteus spp. isolated from domestic animals have been limited to case reports or retrospective studies, or as only a part of surveillance focused on other microorganisms (CORRÊA; CORRÊA, 1992; NELSON; COUTO, 2010; OLIVEIRA et al., 2012; PEREIRA et al., 2004).

Proteus spp. and other enterobacteria produce enzymes that promote resistance to some betalactamic antimicrobials, including cephalosporins and penicillins. Strains that are resistant to various antimicrobials in this group are considered extendedspectrum beta lactamases (ESBL) producers and have gained attention among health professionals in the past few decades (GIGUÈRE et al., 2010). Thus, the aim of present study was to investigate the in vitro antimicrobial multiple resistance index and minimum inhibitory concentrations (MICs) of isolates, as well as the presence of ESBL producers in strains of Proteus mirabilis and Proteus vulgaris isolated from domestic animals among various clinical specimens.

\section{Materials and Methods}

\section{Animals and microorganisms}

In total, 73 Proteus strains isolated from livestock and companion animals were included in this study. The strains were maintained in duplicate in tube racks $\left(25^{\circ} \mathrm{C}\right)$ and frozen $\left(-20^{\circ} \mathrm{C}\right)$ in BHI plus glycerol (15\%).

\section{Microbiology diagnosis}

All clinical specimens used for strain isolation (urine, feces, otologic secretions, skin, abscesses, synovial fluid, organ fragments, and peritoneal fluid) were simultaneously plated on defibrinated sheep blood agar (5\%) and MacConkey agar. Both cultures were maintained under aerobic conditions at $37^{\circ} \mathrm{C}$ for $72 \mathrm{~h}$, with evaluation every $24 \mathrm{~h}$. After 24-48 hour of incubation, the presence of lactose-negative colonies in MacConkey agar and or white-greyish colonies with a strong odor, 2-3 mm diameter, with concentric circles were considered suggestive of Proteus spp. (QUINN et al., 2011; SONGER; POST, 2005). Biochemical characterization of each isolate was performed using $\mathrm{MILi} / \mathrm{EPM} /$ Citrate 
biochemical tests (TRABULSI; ALTERTHUM, 2005). In parallel, colonies compatible with Proteus spp. were subjected to other phenotypic tests, such as catalase, urease, gelatin liquefaction, nitrate reduction, and esculin fermentation tests (MANDELL et al., 2005; MURRAY et al., 2007; TORTORA et al., 2005), for species confirmation.

\section{In vitro antimicrobial sensitivity profile (disk diffusion method)}

All Proteus sp. strains were subjected to in vitro antimicrobial sensitivity testing using the standard disk diffusion method (BAUER et al., 1966). The tests were performed according to recommendations of the Clinical Laboratory Standards Institute (CLSI, 2013).

Twenty-one antimicrobials from ten distinct groups recommended for the treatment of Proteus spp. infections in domestic animals (NELSON; COUTO, 2010; KOENIG, 2012; QUINN et al., 2011; RADOSTITS et al., 2007) and/or humans (MANDELL et al., 2005; MURRAY et al., 2007; O'HARA et al., 2000;) were used in this study as follows: 1) cephalosporin (ceftriaxone, $30 \mu \mathrm{g}$; ceftiofur, $30 \mu \mathrm{g}$; cephalexin, $30 \mu \mathrm{g}), 2$ ) penicillins of wide spectrum (ampicillin, $10 \mu \mathrm{g}$; amoxicillin/clavulanic acid, $30 \mu \mathrm{g}), 3$ ) macrolides (azithromycin, $15 \mu \mathrm{g}$ ), 4) fluoroquinolones (enrofloxacin, $5 \mu \mathrm{g}$; ciprofloxacin, $5 \mu \mathrm{g}$; norfloxacin, $10 \mu \mathrm{g}$; levofloxacin, $5 \mu \mathrm{g}$; marbofloxacin, $5 \mu \mathrm{g}$ ), 5) aminoglycosides (gentamicin, $10 \mu \mathrm{g}$; amikacin, $30 \mu \mathrm{g}$; neomycin, $30 \mu \mathrm{g}$; tobramycin, $10 \mu \mathrm{g}$ ), 6) rifamycin (rifampicin, $5 \mu \mathrm{g}$ ), 7) amphenicols (florfenicol, $30 \mu \mathrm{g}$; chloramphenicol, $30 \mu \mathrm{g}$ ), 8) sulfonamides (sulfamethoxazole/trimethoprim, 25 $\mu \mathrm{g}), 9)$ non-macrolide glycoside (novobiocin, 30 $\mu \mathrm{g}$ ), and 10) carbapenems (imipenem, $10 \mu \mathrm{g}$ ).

\section{Antimicrobial multiple resistance index and antimicrobial resistance profiles}

Multiple antimicrobial resistance indices were calculated by determining the ratio of the number of antimicrobial class(es) against which each isolate was resistant and the total number of tested classes (10 classes). Strains with index values $\geq 0.3$ were considered potential sources of resistance genes (KRUMPERMAN, 1983).

\section{MICs}

All strains were subjected to minimum inhibitory concentration testing (CLSI, 2013) using a commercial kit (M.I.C.E. Evaluator, Oxoid, Hampshire, UK) and four antimicrobials in decreasing concentrations on strips. The tests were carried out according to the manufacturer's instructions. The impregnated strips contained amoxicillin/clavulanic acid (256-0.015 $\mu \mathrm{g} / \mathrm{mL})$, gentamicin $(256-0.015 \mu \mathrm{g} / \mathrm{mL})$, ciprofloxacin (32$0.002 \mu \mathrm{g} / \mathrm{mL})$, and ceftriaxone $(32-0.002 \mu \mathrm{g} / \mathrm{mL})$.

\section{ESBL}

All Proteus isolates were subjected to ESBL phenotypic testing using the disk diffusion method and agar with amoxicillin/clavulanic acid $(30 \mu \mathrm{g})$ in the center, surrounded by aztreonam (30 $\mu \mathrm{g})$, ceftriaxone $(30 \mu \mathrm{g})$, ceftazidime (30 $\mu \mathrm{g})$, and cefoperazone $(30 \mu \mathrm{g})$. The plates were incubated for $24 \mathrm{~h}$ under aerobic conditions at $37^{\circ} \mathrm{C}$, and measurements were obtained per CLSI recommendations (CLSI, 2013). An increases in the inhibition halo diameter or distortions around the beta-lactam drugs (known as the "ghost zone") indicated that an isolate was an ESBL-producer. Klebsiella pneumoniae (ATCC 700603) was used as a positive control.

\section{Sampling, analysis, and ethical guidelines}

The microorganisms used in this study were used based on convenience because of the difficulty in obtaining a large number of Proteus spp. isolates from different infections in domestic animals. Associations between multidrug resistance, source 
animal, and clinical infections were determined by chi-square and Fisher's exact tests (TRIOLA, 2005) using EPI-INFO 6.04v software and considering P $<0.05$ as significant. This study was approved by the Ethics Committee on Animal Use at the School of Veterinary Medicine and Animal Sciences, Univ. Estadual Paulista (UNESP), Botucatu, SP, Brazil, under protocol number 175/2014.

\section{Results}

\section{Strains}

Seventy-three Proteus strains were isolated in sheep blood agar and MacConkey agar from different clinical specimens. Biochemical characterization revealed 69 (94.51\%) P. mirabilis and 4 (5.49\%) P. vulgaris isolates.

\section{Origin of isolates}

Among the 69 P. mirabilis isolates, 25 (34.25\%) were recovered from samples of cystitis, $19(26.01 \%)$ enteritis, 9 (12.33\%) otitis, 3 (4.11\%) abscesses, 3 (4.11\%) arthritis, $3(4.11 \%)$ dermatitis, 2 (2.74\%) conjunctivitis, 1 (1.37\%) omphalitis, 1 (1.37\%) metritis, 1 (1.37\%) peritonitis, 1 (1.37\%) surgical wound secretion, and $1(1.37 \%)$ organ fragment. Of the four $P$. vulgaris isolates, $2(2.74 \%)$ were isolated from cases of cystitis, 1 (1.37\%) of dermatitis, and $1(1.37 \%)$ of metritis. In dogs, cystitis $(n=27$; $48.21 \%)$, enteritis $(n=12 ; 21.42 \%)$, and otitis $(n=8$; $14.29 \%$ ) were the most frequent origins of Proteus isolates. Enteritis was the most common origin of isolates among bovines $(\mathrm{n}=2 ; 22.22 \%)$, equines ( $\mathrm{n}$ $=3 ; 50.0 \%)$, and felines $(\mathrm{n}=2 ; 100.0 \%)$. However, other miscellaneous infections by Proteus species were observed, including abscesses, conjunctivitis, arthritis, surgical wounds, dermatitis, omphalitis, and peritonitis (Table 1).

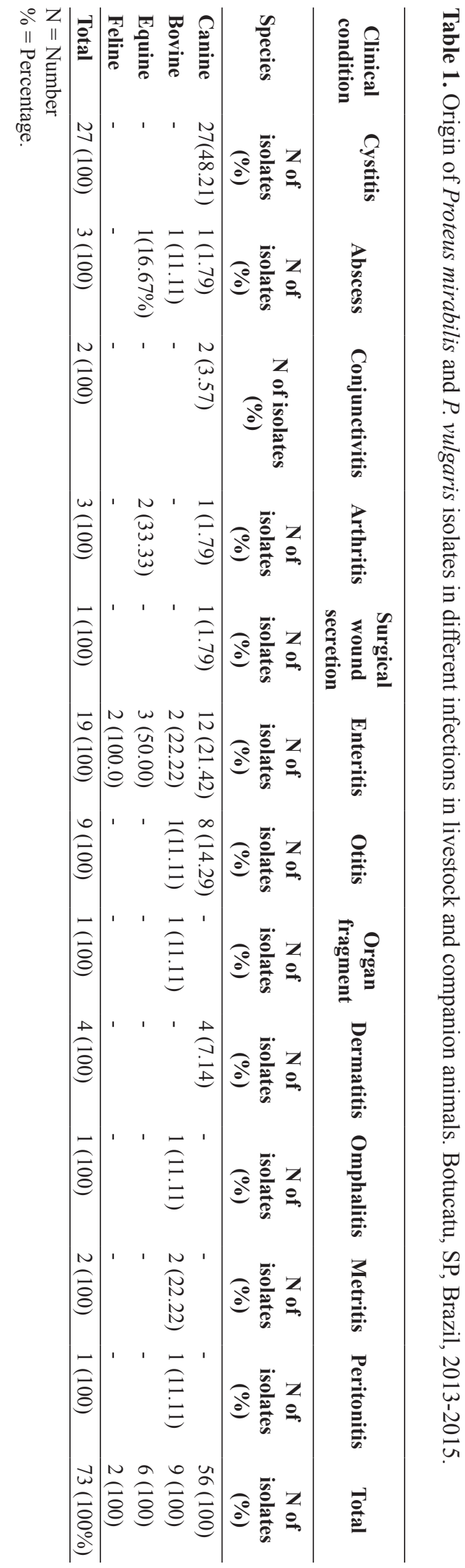


In vitro antimicrobial sensitivity profiles

In the disk diffusion test, isolates presented higher in vitro sensitivities to imipenem (98.63\%), amikacin (95.89\%), norfloxacin (95.89\%), levofloxacin (90.41\%), florfenicol (87.67\%), ceftriaxone (87.64\%), amoxicillin/clavulanic acid $(86.30 \%)$, gentamicin $(86.30 \%)$, and marbofloxacin $(86.30 \%)$. Furthermore, resistance of strains to novobiocin (95.89\%), azithromycin (57.53\%), and sulfamethoxazole/trimethoprim (39.73\%) was observed (Table 2).

Table 2. In vitro antimicrobial sensitivity pattern based on disk diffusion testing of Proteus mirabilis and P. vulgaris strains isolated from domestic animals. Botucatu, SP, Brazil, 2013-2015.

\begin{tabular}{|c|c|c|c|c|}
\hline \multirow{3}{*}{ Group } & \multirow{3}{*}{ Antimicrobials } & \multicolumn{3}{|c|}{ Sensitivity Profile } \\
\hline & & Sensitive & $\begin{array}{l}\text { Partially } \\
\text { sensitive }\end{array}$ & Resistant \\
\hline & & $\mathbf{N}(\%)$ & $\mathbf{N}(\%)$ & $\mathbf{N}(\%)$ \\
\hline \multirow{3}{*}{ Cephalosporin } & Cephalexin & $54(73.97)$ & $3(4.11)$ & $16(21.92)$ \\
\hline & Ceftiofur & $62(84.93)$ & $2(2.74)$ & $9(12.33)$ \\
\hline & Ceftriaxone & $64(87.64)$ & $4(5.48)$ & $5(6.85)$ \\
\hline \multirow{2}{*}{$\begin{array}{l}\text { Penicillin of wide } \\
\text { spectrum }\end{array}$} & Amoxicillin/clavulanic acid & $63(86.30)$ & $3(4.11)$ & $7(9.59)$ \\
\hline & Ampicillin & $48(65.75)$ & $2(2.74)$ & $23(31.51)$ \\
\hline \multirow[t]{2}{*}{ Macrolides } & Azithromycin & $28(38.36)$ & $3(4.11)$ & $42(57.53)$ \\
\hline & Norfloxacin & $70(95.89)$ & $1(1.37)$ & $2(2.74)$ \\
\hline \multirow{3}{*}{ Fluoroquinolones } & Ciprofloxacin & $61(83.56)$ & $7(9.59)$ & $5(6.85)$ \\
\hline & Enrofloxacin & $55(75.34)$ & $6(8.22)$ & $12(16.44)$ \\
\hline & Levofloxacin 66 (90.41) 3 (4. & 1) $4(5.48) \mathrm{M}$ & bofloxacin 63 & 0) 3 (4.11) 7 (9.59) \\
\hline \multirow{4}{*}{ Aminoglycosides } & Gentamicin & $63(86.30)$ & $2(2.74)$ & $8(10.96)$ \\
\hline & Neomycin & $60(82.19)$ & $2(2.74)$ & $11(15.07)$ \\
\hline & Tobramycin & $62(84.93)$ & $3(4.11)$ & $8(10.96)$ \\
\hline & Amikacin & $70(95.89)$ & $0(--)$ & $3(4.11)$ \\
\hline Rifamycins & Rifampicin & $32(43.84)$ & $35(47.94)$ & $6(8.22)$ \\
\hline \multirow{2}{*}{ Amphenicols } & Chloramphenicol & $57(78.08)$ & $3(4.11)$ & $13(17.81)$ \\
\hline & Florfenicol & $64(87.67)$ & $3(4.11)$ & $6(8.22)$ \\
\hline Sulfonamides & Trimethoprim/sulfa & $44(60.27)$ & $0(--)$ & $29(39.73)$ \\
\hline Non-macrolide glycoside & Novobiocin & $3(4.11)$ & $0(--)$ & $70(95.89)$ \\
\hline Carbapenem & Imipenem & $72(98.63)$ & $0(--)$ & $1(1.37)$ \\
\hline
\end{tabular}

$\mathrm{N}=$ Number of isolates

$\%=$ Percentage

Sulfa $=$ Sulfamethoxazole .

\section{Antimicrobial multiple resistance index}

Multidrug resistance values $\geq 0.3$ were found in $33(45.21 \%)$ strains, ranging from 0.1 to 1 .

\section{Multiple resistance profiles}

Distinct profiles of isolates showing multidrug resistance against 3-16 drugs were found. Among isolates with a multidrug resistance profile, the highest occurrence was observed in isolates from $\operatorname{dogs}(n=25 ; 75.76 \%)$, particularly in those with cystitis $(\mathrm{n}=13 ; 52.0 \%)$ (Table 3$)$. Multidrug resistance profiles in bovines, equines, and felines was observed in $12.12 \%(n=4), 6.06 \%(n=2)$, and $6.06 \%(n=2)$ of the isolates, respectively (Table 4$)$. One isolate recovered from cystitis was resistant to 16 of the antimicrobials tested. Only two isolates recovered from cystitis were found to have identical 
profiles (Table 3), although these two isolates were obtained from animals in distinct locations. No statistically association was observed between the multidrug resistance of Proteus species and origin of infections in $\operatorname{dogs}(\mathrm{P}=0.99)$. For bovines, equines, and felines, the most diverse resistance profiles were observed in isolates obtained from feces. A bovine feces isolate was resistant to 11 antimicrobials, while a feline feces isolate was resistant to 10 drugs (Table 4).

Table 3. Multidrug antimicrobial resistance profiles of Proteus mirabilis and P. vulgaris isolates from dogs. Botucatu, SP, Brazil, 2013-2015.

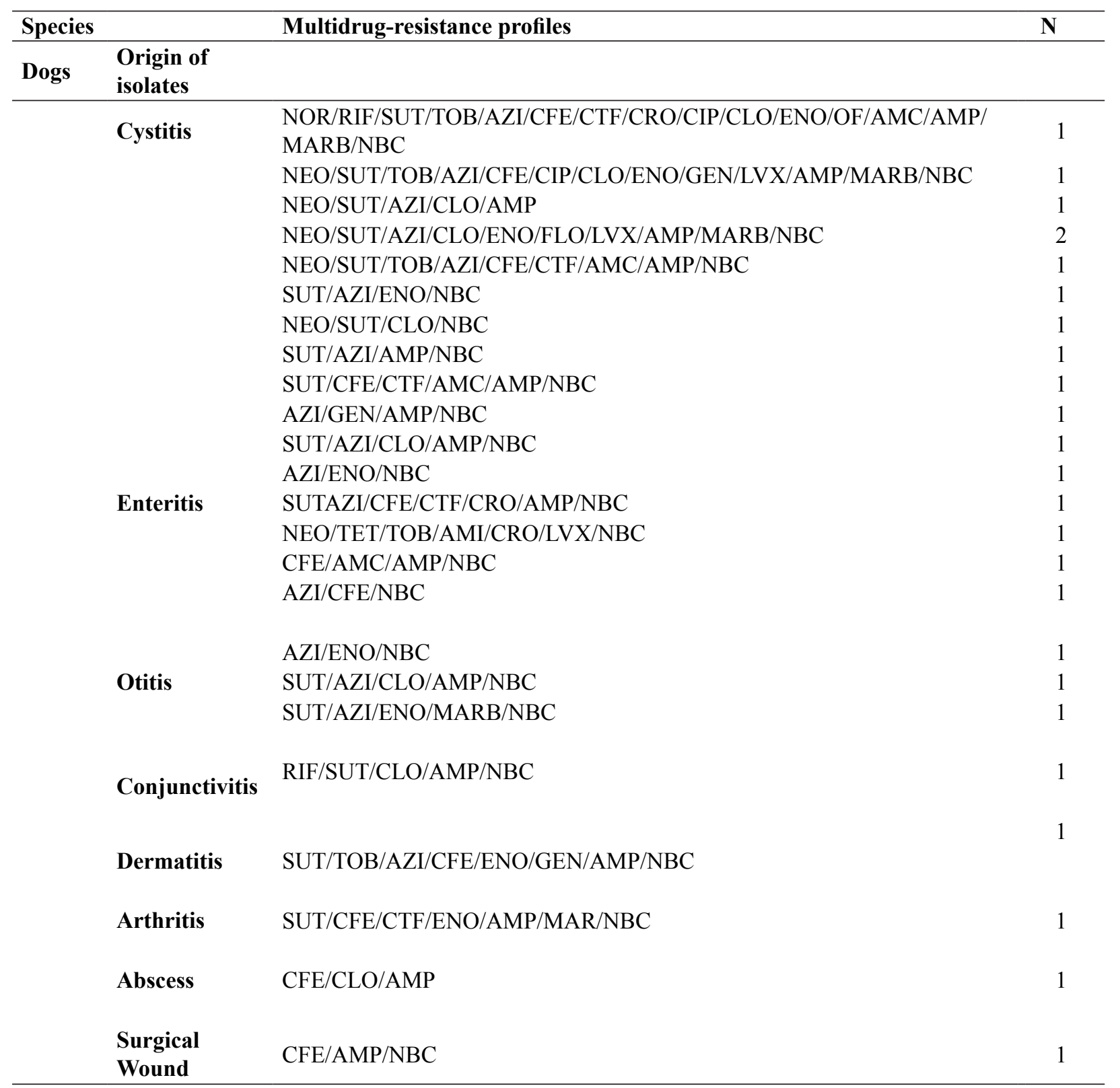

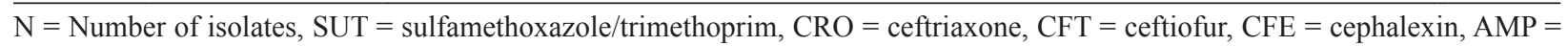
ampicillin, $\mathrm{AMC}=$ amoxicillin/clavulanic acid, $\mathrm{AZI}=$ azithromycin, $\mathrm{ENO}=$ enrofloxacin, $\mathrm{CIP}=$ ciprofloxacin, $\mathrm{NOR}=$ norfloxacin, $\mathrm{LVX}=$ levofloxacin, GEN = gentamicin, $\mathrm{AMI}=$ amikacin, $\mathrm{NEO}=$ neomycin, $\mathrm{TOB}=$ tobramycin, $\mathrm{RIF}=$ rifampicin, $\mathrm{FLO}=$ florfenicol, $\mathrm{CLO}=$ chloramphenicol, $\mathrm{NBC}=$ novobiocin, $\mathrm{MARB}=$ marbofloxacin, $\mathrm{IMI}=$ imipenem. 
Table 4. Multidrug antimicrobial resistance profiles of Proteus mirabilis and P. vulgaris isolates from livestock and cats. Botucatu, SP, Brazil, 2013-2015.

\begin{tabular}{llll}
\hline Species & & Multidrug-resistance profile & N \\
\hline \multirow{2}{*}{ Bovine } & \begin{tabular}{l} 
Origin of \\
isolates \\
\cline { 3 - 4 }
\end{tabular} & & \\
\cline { 3 - 4 } & Organ fragments & SUT/AZI/CFE/CIP/ENO/AMC/AMP/NBC & 1
\end{tabular}

Metritis

RIF/SUT/CFE/CLO/FLO/AMP/NBC

Omphalitis

AZI/CLO/GEN/AMP/NBC

Feces

\section{Equine Isolates Origin}

Feces

NEO/SUT/TOB/GEN/NBC

1

Synovial Fluid $\quad$ SUT/AZI/NBC

1

\begin{tabular}{llll}
\hline Feline & Isolates Origin & & \\
\hline \multirow{2}{*}{ Feces } & NEO/SUT/TOB/AMI/AZI/CFE/CTF/CRO/GEN/NBC & 1 \\
& RIF/SUT/AZI/CFE/NBC & 1 \\
\hline
\end{tabular}

$\mathrm{N}=$ Number of isolates, $\mathrm{SUT}=$ sulfamethoxazole/trimethoprim, $\mathrm{CRO}=$ ceftriaxone, $\mathrm{CFT}=$ ceftiofur, $\mathrm{CFE}=$ cephalexin, $\mathrm{AMP}=$ ampicillin, $\mathrm{AMC}=$ amoxicillin/clavulanic acid, $\mathrm{AZI}=$ azithromycin, $\mathrm{ENO}=$ enrofloxacin, $\mathrm{CIP}=$ ciprofloxacin, $\mathrm{NOR}=$ norfloxacin, $\mathrm{LVX}=$ levofloxacin, $\mathrm{GEN}=$ gentamicin, $\mathrm{AMI}=$ amikacin, $\mathrm{NEO}=$ neomycin, $\mathrm{TOB}=$ tobramycin, $\mathrm{RIF}=$ rifampicin, $\mathrm{FLO}=$ florfenicol, $\mathrm{CLO}=$ chloramphenicol, $\mathrm{NBC}=$ novobiocin, $\mathrm{MARB}=$ marbofloxacin, $\mathrm{IMI}=$ imipenem .

MICs

The MICs revealed that all isolates showed sensitivities of $87.67 \%, 86.30 \%, 84.93 \%$, and $82.19 \%$ to ceftriaxone, gentamicin, ciprofloxacin, and amoxicillin/clavulanic acid, respectively. In contrast, the resistance of isolates to these same antimicrobials was $12.33 \%, 12.33 \%, 12.33 \%$, and $16.43 \%$, respectively. The $\mathrm{MIC}_{50}$ values (minimum inhibitory concentration that inhibited the growth of $50 \%$ of isolates) for amoxicillin/clavulanic acid, ceftriaxone, ciprofloxacin, and gentamicin were 1.0, $0.004,0.03$, and $1.0 \mu \mathrm{g} / \mathrm{mL}$, respectively. It was not possible to calculate the $\mathrm{MIC}_{90}$ (minimum inhibitory concentration that inhibited the growth of $90 \%$ of isolates) because the effectiveness values (MICs) for these antimicrobials were $72.6 \%, 87.7 \%, 86.0 \%$, and $86.0 \%$, respectively, i.e., below $90 \%$ (Table 5).

\section{ESBL}

ESBL-producers were identified in two $(2.7 \%)$ canine isolates, one obtained from the skin (animal 39 ) and another recovered from feces (animal 42). 


\section{Statistical analysis}

There was no statistically significant $(\mathrm{P}>0.05)$ association between the antimicrobial sensitivity of isolates between MICs and disk diffusion values, despite some discrepancies between the results of these methods (Tables 2 and 5). There was a bias toward higher resistance of isolates on MICs (Table 5) than disk diffusion tests (Table 2), although this difference was not statistically significant $(\mathrm{P}>0.05)$.

\section{Discussion}

Proteus mirabilis and $P$. vulgaris have been identified as the causal agents of various diseases in livestock, companion animals and wildlife (QUINN et al., 2011; SONGER; POST, 2005). The present study detected a high frequency of $P$. mirabilis in dogs with urinary tract infections, similar to that reported in previous studies (MANDELL et al., 2005; NELSON; COUTO, 2010), confirming their pathogenicity in this system. Urinary tract infections caused by enterobacteria in domestic animals may be associated with the proximity of the genital region to the perineum that is contaminated with feces, which may facilitate urethral infections by this group of pathogens, including the Proteus spp. (KOENIG, 2012; SIQUEIRA et al., 2009; ZIMMEL, 2007).

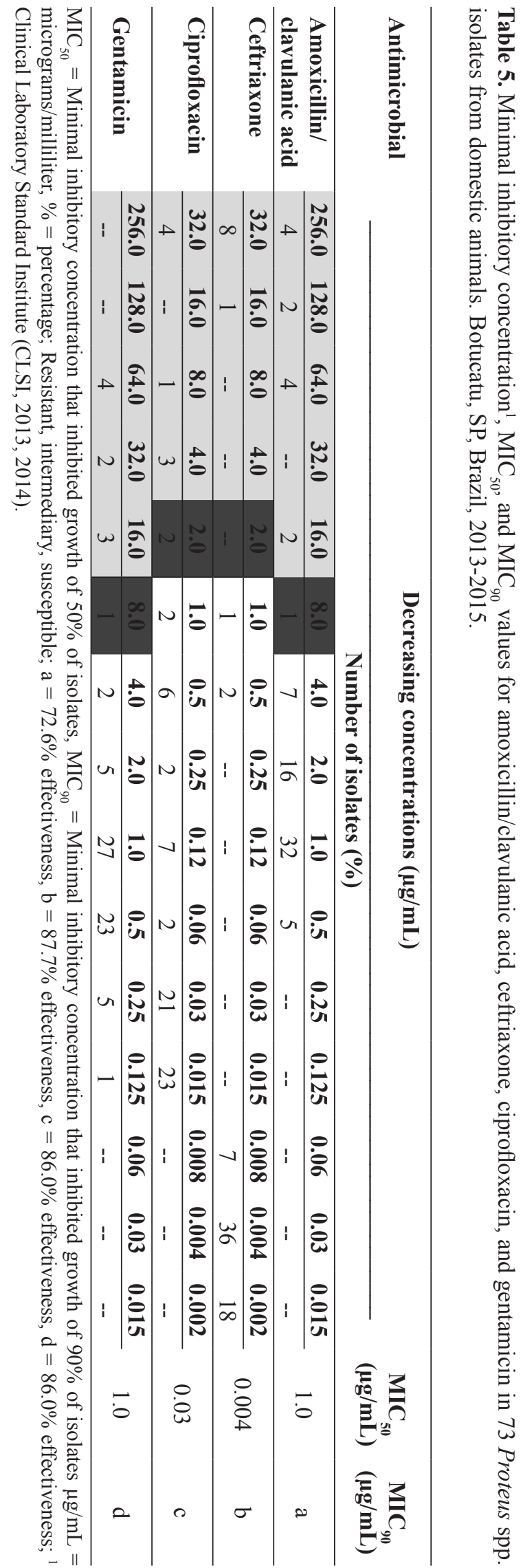


Most previous studies of the pathogenicity of Proteus spp. in domestic animals were based on urinary tract infections. Among the factors associated with pathogenicity, the following are considered particularly important: fimbriae, which promote the adhesion of pathogens to uroepithelial cells, (MANDELL et al., 2005), ZapA proteins, which degrade surface immunoglobulins in the urinary tract mucosa (SONGER; POST, 2005), and peritrichous flagella, which facilitate dissemination from the urethra (QUINN et al., 2011). In addition, urease production hydrolyzes urea and alters the local $\mathrm{pH}$, favoring renal calculi that block the passage of urine and lead to damage of local cells by excess ammonia, predisposing the animals to urolithiasis (MANDELL et al., 2005). Proteus spp. located inside the calculi can limit immune responses and antimicrobial actions, promoting chronic urinary system infections as well as dissemination of the organism to the kidneys, causing pyelonephritis and occasionally septicemia (SONGER; POST, 2005). A combination of these virulence factors increases the pathogenicity of Proteus spp. to domestic animals (KOENIG, 2012; QUINN et al., 2011).

Despite the high occurrence of urinary tract infections in this current study, Proteus spp. were isolated from various other infections, including abscesses, conjunctivitis, arthritis, dermatitis, enteritis, otitis, metritis, peritonitis, and umbilical infections and were isolated from organs in canine, bovine, equine, and feline species. These results are similar to those obtained in Brazil (CORREA and CORRÊA, 1992) and other countries (KOENIG, 2012; PLUNKET, 2000; QUINN et al., 2011; RADOSTITS et al., 2007), who reported a variety of Proteus spp. infections in livestock and companion animals. These data reinforce the opportunistic behavior of Proteus spp. in domestic animals, as these organisms are found in the intestinal microbiota, water, food, and breeding facilities and as contaminants of tools commonly used for animals; additionally, they may infect any organ or tissue (QUINN et al., 2011; SONGER; POST, 2005).
The identification of Proteus spp. in the otitis and dermatitis of livestock and companion animals (KOENIG, 2012; RADOSTITS et al., 2007; QUINN et al., 2011) has been reported previously (GRECI et al., 2011; MEGID et al., 1990; OLIVEIRA et al., 2012). These infections are closely associated with predisposing conditions such as high humidity, which favor contamination of water by Proteus spp. in breeding facilities (QUINN et al., 2011; SONGER; POST, 2005).

Reports describing Proteus spp. as a primary pathogen of domestic animals in enteric infections are controversial (NELSON; COUTO, 2010; PEREIRA et al., 2004; QUINN et al., 2011; RADOSTITS et al., 2007), but their role as the causative agent of diarrhea in dogs (KOENIG, 2012) and domestic ruminants (PEREIRA et al., 2004; RADOSTITS et al., 2007) has been described. In this study, P. mirabilis was isolated from dogs, bovines, equines, and felines with enteritis, indicating that the microorganism should be included in the differential diagnosis for enteric diseases in livestock and companion animals.

In Brazil, Proteus spp. infections in domestic animals have been restricted to case reports and retrospective surveillance or studies focused on other microorganisms (CORRÊA; CORRÊA, 1992; NELSON; COUTO, 2010; OLIVEIRA et al., 2012; PEREIRA et al., 2004). However, Proteus infections may be misdiagnosed or these pathogens may be considered a contaminant even when they are the primary agents of disease (O'HARA et al., 2000). Except in fecal samples, P. mirabilis and $P$. vulgaris isolates were obtained predominantly in pure cultures from animals with various extraintestinal infections. Despite the presence of Proteus sp. in animal feces and in breeding facilities (QUINN et al., 2011; SONGER; POST, 2005), the diversity of conditions associated with these microorganisms suggest the need for veterinary laboratories to consider this pathogen a primary agent of various infections in livestock and companion animals.

Isolation of $P$. mirabilis and $P$. vulgaris, particularly from companion animals that have close 
contact with humans, represents a public health concern because of the potential for transmission of the pathogen to humans through different secretions and excretions, especially to immunosuppressed patients, children, and the elderly, or through nosocomial infections (BAHASHWAN; SHAFEY, 2013; MANDELL et al., 2005; O'HARA et al., 2000; TORTORA et al., 2005).

Aminoglycosides (amikacin, gentamicin, and tobramycin), amoxicillin/clavulanate acid, cephalosporin (ceftiofur, ceftriaxone), fluoroquinolones (ciprofloxacin, enrofloxacin), chloramphenicol, rifamycin, and sulfonamides/ trimethoprim are considered first-line antimicrobials for treating Proteus spp. infections in domestic animals (KOENIG, 2012; LUZZARO et al., 2001; RADOSTITS et al., 2007). In the current study, Proteus strains showed the highest in vitro sensitivities to imipenem, norfloxacin, amikacin, levofloxacin, ceftriaxone, florfenicol, ceftriaxone, marbofloxacin, and amoxicillin/clavulanic acid. This suggests the effectiveness of carbapenems, fluoroquinolones, aminoglycosides, cephalosporins, and amphenicols, as well as synergistic combinations (sulfonamides/trimethoprim; amoxicillin/clavulanic acid) as first-line drugs for treating infections by this pathogen in domestic animals.

The in vitro effectiveness of imipenem in our isolates may be attributed to the restricted use of this drug in veterinary medicine (KOENIG, 2012; OLIVEIRA et al., 2006), despite its indication as a drug of choice in human Proteus infections (MANDELL et al., 2005; RENNIE; JONES, 2014). Similarly, the high in vitro effectiveness of levofloxacin and marbofloxacin against Proteus isolates in this study may have been observed because fluoroquinolones have only recently been used in veterinary medicine, particularly in dogs and equines. Marbofloxacin is a fourth-generation fluoroquinolone that was first introduced in Europe and is currently used by via parenteral administration to treat pneumonia in bovines and swine through the intramammary route for bovine mastitis and orally for companion animals (GIGUÈRE et al., 2010). European studies of the in vitro sensitivity of different bacterial pathogens isolated from bovines (E. coli, Salmonella spp., Mannheimia haemolytica, Pasteurella multocida, Staphylococcus aureus, and Streptococcus spp.) and from companion animals (E. coli, Pseudomonas aeruginosa, Staphylococcus intermedius) have shown success with the use of marbofloxacin (de MEUNIER et al., 2004a,b). This is suggestive that marbofloxacin can be used as an alternative antimicrobial to treat various clinical conditions in animals, particularly those of the urinary, respiratory, and dermatological tracts (KROEMER et al., 2014).

Bacterial resistance to antimicrobials and the emergence of multidrug-resistant microorganisms are emergent public health threats (GIGUÈRE et al., 2010; RIBEIRO, 2008; TAVARES, 2007; TRABULSI; ALTHERTUM, 2005). In veterinary medicine, multi-resistant microorganisms likely result from the excess use of antimicrobials as "growth promoters" for poultry and swine, use of prophylaxis measures for specific diseases (such as in dry cow therapy), and improper use of some drugs (underdosing, overdosing and treatment discontinuation) (ANDRADE; GIUFFRIDA, 2008; GIGUÈRE et al., 2010; RIBEIRO, 2008).

Resistance of Proteus spp. to novobiocin, azithromycin, and sulfamethoxazole/trimethoprim was observed in the 73 strains of Proteus spp. in this study. The resistance of isolates to novobiocin and sulfamethoxazole/trimethoprim may be attributed to the use of these drugs in veterinary medicine since 1950 (GIGUÈRE et al., 2010; TAVARES, 2007), with prolonged selective pressure for multidrug resistance of the strains.

Different strategies have been proposed for monitoring the multidrug resistance of bacteria, particularly to conventional drugs (TAVARES, 2007). Although the antimicrobial multiple resistance index was originally used for E. coli (KRUMPERMAN, 1983), this index has recently been used for other enterobacteria, including gram- 
positive species (GIRARDINI et al., 2013). In this study, multidrug resistance index $\geq 0.3$ was observed in 33 (45.21\%) isolates, particularly from dogs $(n=25 ; 75.76 \%)$ with cystitis $(n=13 ; 52 \%)$. The multidrug resistance found in our isolates associated with canine cystitis indicates the need for the rational use of antimicrobials to treat this clinical condition in companion animals. Despite the diverse antimicrobial resistance profiles observed in isolates obtained from livestock and companion animals in the current study (with simultaneous resistance against 3-16 drugs), only two $P$. mirabilis strains isolated from dogs with cystitis showed the same drug-resistance profile (resistance simultaneously to neomycin, sulfamethoxazole/ trimethoprim, azithromycin, chloramphenicol, enrofloxacin, florfenicol, levofloxacin, ampicillin, marbofloxacin, and novobiocin), suggesting the transmission and maintenance of resistant strains in the same breeding environment or region. However, this hypothesis was rejected because of the different origins of the isolates.

The MIC is the lowest in vitro concentration of a specific antimicrobial that can inhibit the growth of a microorganism. In general, the MIC values of amoxicillin/clavulanic acid, ciprofloxacin, ceftriaxone, and gentamicin observed in Proteus isolates were consistent with those previously described for domestic animals (GIGUÈRE et al., 2010; GROBBEL et al., 2007). Comparison of the in vitro sensitivities of the isolates to the MICs and disk diffusion method showed similar results, with identical values for ceftriaxone and gentamicin, lower effectiveness of ciprofloxacin, and greater effectiveness of amoxicillin/clavulanic acid particularly in the MIC test. These results indicate that both in vitro techniques were effective for assessing the sensitivity profiles of Proteus isolates in this study.

Carbapenem (imipenem)-resistant and ESBLproducing enterobacteria are considered one of the most serious public health problems worldwide (GIGUÈRE et al., 2010). This study found only one imipenem-resistant isolate, which may be attributed to the infrequent use of this drug in veterinary medicine (GIGUÈRE et al., 2010; OLIVEIRA et al., 2006). However, although imipenem is the drug of choice for treating infections by Proteus sp. in humans (BAHASHWAN; SHAFEY, 2013), isolates resistant to this drug having an animal origin are a recent public health concern (RENNIE; JONES, 2014).

Of the 73 strains of Proteus spp. enrolled in this study, only two were EBSL-positive. Nevertheless, studies involving Proteus spp. and other enterobacteria from different countries including Brazil (SIQUEIRA et al., 2014) frequently identified ESBL-producing strains in domestic animals (THOMSON, 2010), highlighting the potential for ESBL-producers strains to be transmitted from animals-to-humans (SCHAUFLER et al., 2015). In humans, ESBL-producing enterobacteria are closely associated with nosocomial infections (GIGUÈRE et al., 2010). High hospital mortality was reported in 99 patients with septicemia resulting from multiple drug-resistant P. mirabilis infection; 50\% of these patients were infected with ESBL-positive strains, and 30 of these individuals died from these infections (TUMBARELLO et al., 2012).

Multidrug-resistant and ESBL-positive $P$. mirabilis and $P$. vulgaris isolates observed in our study obtained from different domestic animals confirm the need for increasing concern among health professionals regarding multidrugresistant bacteria (GIGUÈRE et al., 2010). In vitro antimicrobial sensitivity tests cannot predict the in vivo effectiveness of drugs in all cases because other factors such as the etiologic agent, drug, inflammatory process, and tissues involved also contribute to the resolution of infection. However, previous studies of the in vitro sensitivity patterns of bacteria may increase the success rates in treatment protocols for animal infections (GIGUÈRE et al., 2010; RIBEIRO, 2008). Based on our findings, the selection of first-line drugs for treatment should be based on local in vitro resistance patterns. Indeed, 
the responsible use of antimicrobials for domestic animals is an emergent precept of the "One Health" concept, to conserve these drugs for human therapy approaches (RABINOWITZ et al., 2013).

\section{Conclusion}

This study highlights the diversity of the clinical manifestations and opportunistic behaviors of Proteus spp. infections in livestock and companion animals, showing their predominance in urinary tract infections, enteritis, and otitis. Our results also reinforce the importance of determining the in vitro susceptibility pattern of isolates before initiating therapy to improve antimicrobial therapy approaches. Furthermore, the high occurrence of resistant isolates and presence of ESBL-producing P. mirabilis strains isolated from dogs indicates multidrug resistance, reinforcing the need for the rational use of antimicrobials when treating domestic animals.

\section{References}

ANDRADE, S. F.; GIUFFRIDA, R. Quimioterápicos antimicrobianos e antibióticos. In: ANDRADE, S. F. Manual de terapêtica veterinária. São Paulo: Roca, 2008. cap. 3, p. 26-72.

BAHASHWAN, S. A.; EL SHAFEY, H. M. Antimicrobial resistence patterns of Proteus isolates from clinical specimens. European Scientific Journal, v. 9, n. 27, p. $188-202,2013$.

BAUER, A. W.; KIRBY, W. M. M.; SHERRIS, J. C.; TURCK, M. Antibiotic susceptibility testing by a standardized single disk method. American Journal of Clinical Pathology, London, v.45, n. 4, p.493-496, 1966.

CLINICAL AND LABORATORY STANDARDS INSTITUTE - CLSI. NCCLS. Performance standards for antimicrobial susceptibility testing. Twenty-third information supplement. Wayne, USA; CLSI, jan. 2013. $206 \mathrm{p}$.

Wayne, USA; CLSI, 2014.

Twenty-fourth information Supplement.

CORRÊA, W. M.; CORRÊA, C. N. M. Enfermidades infecciosas dos mamíferos domésticos. $2^{\text {nd }}$ ed. Rio de Janeiro: Medsi, 1992. 843 p.
GIGUÈRE, S.; PRESCOTT, J. F.; BAGGOT, J. D.; WALKER, R. D.; DOWLING, P. M. Terapia antimicrobiana em medicina veterinária. São Paulo: Roca, 2010. 683 p.

GIRARDINI L. K.; GRESSLER L. T.; COSTA M. M.; BOTTON S. A.; PELLEGRINI, D. C. P.; VARGAS, A. C. Perfil de suscetibilidade antimicrobiana e presença do gene vapA em Rhodococcus equi de origem humana, ambiental e equina. Pesquisa Veterinária Brasileira, Rio de Janeiro, v. 33, n. 6, p. 735-740, 2013.

GRECI, V.; DI GIANCAMILLO, R.; LOMBARDO, R.; GIUDICE, C.; BANCO, B.; MORTELLARO, C. M. Middle ear cholesteatoma in 11 dogs. Canadian Veterinary Journal, Ontario, v. 52, n.6, p. 631-636, 2011.

GROBBEL, M.; LÜBKE-BECKER, A.; ALESÍK, E.; SCHWARZ, S.; WALLMANN, J.; WERCKENTHIN, C.; WIELER, L. H. Antimicrobial susceptibility of Klebsiella spp. and Proteus spp. from various organ systems of horses, dogs and cats as determined in the BfT-GermVet monitoring program 2004-2006. Berl Munch Tierarztl Wochenschr, Berlim, v. 120, n. 9-10, p. 402-411, 2007.

KOENIG, A. Gram-negative bacterial infections. In: GREENE, C. E. Infectious diseases of the dog and cat. 4. ed. St. Louis, Missouri: Elsevier Saunders, 2012. p. 349-359.

KROEMER, S.; EL GARCH, F.; GALLAND, D.; PETIT, J. L.; WOEHRLE, F.; BOULOUIS, H. J. Antibiotic susceptibility of bacteria isolated from infections in cats and dogs throughout Europe (2002-2009). Comparative Immunology, Microbiology and Infectious Diseases, Amsterdã, v. 37, n. 2, p. 97-108, 2014.

KRUMPERMAN, P. H. Multiple antibiotic resistance indexing of Escherichia coli to identify high-risk sources of fecal contamination of foods. Applied Environmental Microbiology, Washington, v. 46, n. 1, p. 165-170, 1983.

LUZZARO, F.; PERILLI, M.; AMICOSANTE, G.; LOMBARDI, G.; BELLONI, R.; ZOLLO, A.; BIANCHI, C.; TONIOLO, A. Properties of multidrug-resistant, ESBL-producing Proteus mirabilis isolates and possible role of $\beta$-lactam $/ \beta$-lactamase inhibitor combinations. International Journal of Antimicrobial Agents, Amsterdã, v. 17, n. 2, p. 131-135, 2001.

MANDELL, G. M.; BENNETT, J. E.; DOLIN, R. Principles and practices of infectious diseases. $6^{\text {th }} \mathrm{ed}$. Philadelphia: Elsevier, 2005. v. 2, 3661 p.

MEGID, J.; FREITAS, J. C.; MÜLLER, E. E.; COSTA, L. L. S. Otite canina: etiologia, sensibilidade antibiótica e susceptibilidade animal. Semina Ciência Agrárias, Londrina, v. 11, n. 1, p. 45-48, 1990. 
MEUNIER, D. de; ACAR, J. F.; MARTEL, J. L.; KROEMER, S.; VALLÉ, M. Seven years survey of susceptibility to marbofloxacin of bovine pathogenic strains from eight European countries. International Journal of Antimicrobial Agents, Amsterdã, v. 24, n. 3, p. 268-78, 2004a.

MEUNIER, D. de; ACAR, J. F.; MARTEL, J. L.; KROEMER, S.; VALLÉ, M. A seven-year survey of susceptibility to marbofloxacin of pathogenic strains isolated from pets. International Journal of Antimicrobial Agents, Amsterdã, v. 24, n. 6, p. 592-8, 2004 b.

MURRAY, P. R.; BARON, E. J.; JORGENSEN, J. H.; LANDRY, M. L.; PFALLER, M. A. Manual of clinical microbiology. $9^{\text {th }}$ ed. Washington, ASM Press, v. 1, 2007. $1267 \mathrm{p}$.

NELSON, R. W.; COUTO, C. G. Medicina interna de pequenos animais. $4^{\text {th }}$ ed. Rio de Janeiro: Elsevier, 2010. p. 663-669.

O'HARA, C. M.; BRENNER, F. W.; MILLER, J. M. Classification, identification, and clinical significance of Proteus, Providencia, and Morganella. Clinical Microbiology Reviews, Washington, v. 13, n. 4, p. 534546, 2000.

OLIVEIRA, L. C.; BRILHANTE, R. S. N.; CUNHA, A. M. S.; CARVALHO, C. B. M. Perfil de isolamento microbiano em cães com otite média e externa associadas. Arquivo Brasileiro de Medicina Veterinária e Zootecnia, Belo Horizonte, v. 58, n. 6, p. 1009-1017, 2006.

OLIVEIRA, V. B.; RIBEIRO, M. G.; ALMEIDA, A. C. S.; PAES, A. C.; CONDAS, L. A. Z.; LARA, G. H. B.; FRANCO, M. M. J.; FERNANDES, M. C.; LISTONI, F. J. P. Etiologia, perfil de sensibilidade aos antimicrobianos e aspectos epidemiológicos na otite canina: estudo retrospectivo de 616 casos. Ciências Agrárias, Londrina, v. 33, n. 6, p. 2367-2374, 2012.

PEREIRA, R. N.; ÁVILA, F. A.; FERNANDES, S. A. Estudo etiológico do perfil epidemiológico da salmonelose em bezerros e da sensibilidade aos antimicrobianos na região de Ribeirão Preto, SP. Ars Veterinária, Jaboticabal, v. 20, n. 1, p. 62-66, 2004.

PHILPOT, W. N., NICKERSON, S. C. Vencendo a luta contra a mastite. São Paulo: Westfalia Landtechnik do Brasil, 2002. 192 p.

PLUNKET, S. J. Emergency procedures for the small animal veterinarian. Philadelphia: Saunders, 2000. 574 p.

QUINN, P. J.; MARKEY, B. K.; LEONARD, F. C.; FITZPATRICK, E. S.; FANNING, S.; HARTIGAN, P. J.
Veterinary microbiology and microbial diseases. 2. ed. UK: Wiley-Blackwell, 2011. 1231 p.

RABINOWITZ, P. M.; KOCK, R.; KACHANI, M.; KUNKEL, R.; THOMAS, J.; GILBERT, J.; WALLACE, R.; BLACKMORE, C.; WONG, D.; KARESH, W.; NATTERSON, B.; DUGAS, R.; RUBIN, C. Toward proof of concept of a one health approach to disease prediction and control. Emerging Infectious Diseases, Atlanta, v. 19, n. 12, p.1-7, 2013.

RADOSTITS, O. M.; GAY, C. C.; HINCHCLIFF, K. W.; CONSTABLE, P. D. Veterinary medicine: a textbook of the diseases of cattle, horses, sheep, pigs, and goats. $10^{\text {th }}$ ed. Philadelphia: Saunders Elsevier. 2007.

RENNIE, R. P.; JONES, R. N. Effects of breakpoint changes on carbapenem susceptibility rates of Enterobacteriaceae: Results from the SENTRY Antimicrobial Surveillance Program, United States, 2008 to 2012. Canadian Journal of Infectious Disease \& Medical Microbiology, Ontario, v. 25, n. 5, p. 285-287, 2014.

RIBEIRO, M. G. Princípios terapêuticos na mastite em animais de produção e de companhia. In: ANDRADE, S. R. F. Manual de terapêutica veterinária. $3^{\text {rd }}$ ed. São Paulo, Roca, 2008. p. 759-771.

SCHAUFLER, K.; BETHE,A. B.; LÜBKE-BECKER,A.; EWERS, C.; KOHN, B.; WIELER, L. H.; GUENTHER, $\mathrm{S}$. Putative conection between multiresistant extendedspectrum beta-lactamase (ESBL)-producing Escherichia coli in dog feces from a veterinary campus and clinical isolates of dogs. Infection Ecology \& Epidemiology, London, v. 5, p. 1-5, 2015.

SIQUEIRA, A. K.; ALVES, T. S.; FERRAZ, M. M. G.; FRANCO, M. M. J.; MOTTA, R. G.; LISTONI, F.J.P.; SILVA, A. V.; RIBEIRO, M. G.; LEITE, D. S. Resistência antimicrobiana em coliformes totais isolados de tanques de refrigeração de leite bovina. Atas de Saúde Ambiental, São Paulo, v. 2, n. 3, p. 2-15, 2014.

SIQUEIRA, A. K.; RIBEIRO, M. G.; LEITE, D. S.; TIBA, M. R.; MOURA, C. D.; LOPES, M. D.; PRESTES, N. C.; SALERNO, T.; SILVA, A. V. Virulence factors in Escherichia coli strains isolated from urinary tract infection and pyometra cases and from feces of healthy dogs. Research in Veterinary Science, Amsterdã, v. 86, n. 2, p. 206-210, 2009.

SONGER, J. G.; POST, K. W. Veterinary microbiology. Bacterial and fungal agents of animal disease. St Louis, Missouri: Elsevier Saunders, 2005. 687 p. 
TAVARES, W. Antibióticos e quimioterápicos para o clínico. São Paulo: Atheneu, 2007. 585 p.

THOMSON, K. S. Extended-spectrum- $\beta$-lactamase, AmpC, and carbapanemase issues. Journal of Clinical Microbiology, Washington v. 48, n. 4, p. 1019-1025, 2010.

TORTORA, G. J.; FUNKE, B. R.; CASE, C. L. Microbiologia. 8. ed. São Paulo: Artmed, 2005. 894 p.

TRABULSI, L. R.; ALTERTHUM, F. Microbiologia. 4. ed. São Paulo: Atheneu, 2005. 718 p.

TRIOLA, M. F. Introdução à estatística. 9. ed. Rio de Janeiro: LTC, 2005. 682 p.
TUMBARELLO, M.; TRECARICHI, E. M.; FIORI A.; LOSITO, A. R.; D'INZEO, T.; CAMPANA, L.; RUGGERI, A.; DI MECO, E.; LIBERTO, E.; FADDA G.; CAUDA, R.; SPANU, T. Multidrug-resistant Proteus mirabilis bloodstream infection: risck factors and outcomes. Antimicrobial Agents and Chemotherap, Washington, v. 56, n. 6, p. 3224-3231, 2012.

ZIMMEL, D. N. Urinary tract infections. In: SELLON, D. C.; LONG, M. T. Equine infectious diseases. 9. ed. St. Lous, Missouri: Elsevier, 2007. cap. 9, p. 103-106. 
